\title{
Hydrogen sulfide and organic carbon at the sediment-water interface in coastal brackish Lake Nakaumi, SW Japan
}

\author{
Saburo Sakai $\cdot$ Masaru Nakaya $\cdot$ Yoshikazu Sampei • \\ David L. Dettman · Katsumi Takayasu
}

Received: 20 December 2011/ Accepted: 30 July 2012/Published online: 22 August 2012

(C) The Author(s) 2012. This article is published with open access at Springerlink.com

\begin{abstract}
The relationship among $\mathrm{H}_{2} \mathrm{~S}$, total organic carbon (TOC), total sulfur (TS) and total nitrogen contents of surface sediments $(0-1 \mathrm{~cm})$ was examined to quantify the relationship between $\mathrm{H}_{2} \mathrm{~S}$ concentrations and TOC content at the sediment water interface in a coastal brackish lake, Nakaumi, southwest Japan. In this lake, bottom water becomes anoxic during summer due to a strong halocline. Lake water has ample dissolved $\mathrm{SO}_{4}{ }^{2-}$ and the surface sediments are rich in planktic organic matter (C/N 7-9), which is highly reactive in terms of sulfate reduction. In this setting the amount of TOC should be a critical factor regulating the activity of sulfate reduction and $\mathrm{H}_{2} \mathrm{~S}$ production. In portions of the lake where sediment TOC content is less than $3.5 \%, \mathrm{H}_{2} \mathrm{~S}$ was very low or absent in both bottom and pore waters. However, in areas with
\end{abstract}

S. Sakai $(\square)$

Institute of Biogeosciences, Japan Agency for Marine-Earth

Science and Technology, 2-15 Natsushima, Yokosuka 237-0061,

Kanagawa, Japan

e-mail: saburos@jamstec.go.jp

M. Nakaya

WDC Co. Ltd., 4-5 Suwa, Yokkaichi, Mie 510-0085, Japan

Y. Sampei

Department of Geosciences, Interdisciplinary Faculty of Science and Engineering, Shimane University, 1060 Nishikawatsu,

Matsue 690-8504, Shimane, Japan

D. L. Dettman

Department of Geosciences, University of Arizona,

Gould-Simpson Building, 1040 E 4th St., Tucson,

AZ 85721, USA

K. Takayasu

Shimane University, 1060 Nishikawatsu, Matsue,

Shimane 690-8504, Japan
TOC $>3.5 \%, \mathrm{H}_{2} \mathrm{~S}$ was correlated with TOC content (pore water $\mathrm{H}_{2} \mathrm{~S}(\mathrm{ppm})=13.9 \times$ TOC $(\%)-52.1$, correlation coefficient: 0.72 ). $\mathrm{H}_{2} \mathrm{~S}$ was also present in areas with sediment TS above $1.2 \%$ (present as iron sulfide), which suggests that iron sulfide formation is tied to the amount of TOC. Based on this relationship, $\mathrm{H}_{2} \mathrm{~S}$ production has progressively increased after the initiation of land reclamation projects in Lake Nakaumi, as the area of sapropel sediments has significantly increased. This TOC- $\mathrm{H}_{2} \mathrm{~S}$ relationship at sediment-water interface might be used to infer $\mathrm{H}_{2} \mathrm{~S}$ production in brackish-lagoonal systems similar to Lake Nakaumi, with readily available $\mathrm{SO}_{4}{ }^{2-}$ and reactive organic matter.

Keywords Hydrogen sulfide - Total organic carbon . Sediment-water interface $\cdot$ Brackish water environment

\section{Introduction}

In restricted coastal brackish water bodies hypolimnion waters often becomes anoxic due to stratification by a halocline, which allows hydrogen sulfide $\left(\mathrm{H}_{2} \mathrm{~S}\right)$ production in the surface sediments. Understanding the relationship between $\mathrm{H}_{2} \mathrm{~S}$ production and bottom environments in coastal brackish lakes is critically important because $\mathrm{H}_{2} \mathrm{~S}$ has a negative effect on aquatic and benthic ecosystems in these environments and can seriously harm fishery production. Previous studies have shown that $\mathrm{H}_{2} \mathrm{~S}$ is produced by the reduction of interstitial dissolved sulfate by sulfate reducing bacteria using sedimentary organic matter as a reducing agent and energy source (Berner 1984). The availability of dissolved sulfate and organic matter, are the factors controlling $\mathrm{H}_{2} \mathrm{~S}$ concentration. In a coastal brackish lake system seawater typically supplies ample sulfate so 
that the reactivity and amount of organic matter in sapropelic sediments are thought to be the primary limiting factor in the production of $\mathrm{H}_{2} \mathrm{~S}$ by bacterial sulfate reduction. Boudreau and Westrich (1985) showed that the reactivity of organic matter for the sulfate reduction decreases with time and with an increase in available oxygen. In particular, surface sediments, which contain large amounts of the freshly deposited planktic organic compounds, are very important in the production of $\mathrm{H}_{2} \mathrm{~S}$ by sulfate reducing bacteria (Berner 1984). These studies also suggested that the amount of organic matter available to microorganisms in the surface sediments is a critical factor regulating the activity of the sulfate reduction and $\mathrm{H}_{2} \mathrm{~S}$ production (Ramm and Bella 1974; Nedwell and Abram 1979), however the quantitative relationship between $\mathrm{H}_{2} \mathrm{~S}$ production and sedimentary organic matter (i.e., total organic carbon content; TOC) at the sediment-water interface (SWI) has not been explored. This study examines $\mathrm{H}_{2} \mathrm{~S}$ and TOC content at the sediment water interface in coastal brackish Lake Nakaumi, where bottom sediments are rich in planktic organic matter (Sampei et al. 1997a) and summer anoxia is common in bottom waters due to a strong picnocline (Sakai et al. 2004).

\section{Materials and methods}

Lake Nakaumi, in southwest Japan, has an area of $86.8 \mathrm{~km}^{2}$ with an average water depth of $5.4 \mathrm{~m}$. It was formed by the growth of the Yumigahama sand bar in combination with sea level rise after the last glacial period (Tokuoka et al. 1990). Seawater enters through the SakaiStrait, and river water flows in from the Ohashi River (Fig. 1). The two bodies of water, having different densities, form a vertical gradient of chemical properties in the lake. The salinity of the epilimnion of the lake water is typically about $17 \mathrm{psu}$ and that of the hypolimnion is about 27 psu (Date et al. 1989). The vertical gradient in salinity increases during the summer, leading to oxygen-poor or anoxic bottom waters, indicating that the lake bottom may be below the redox boundary in this season.

The vertical distribution of water temperature, salinity, DO, and $\mathrm{H}_{2} \mathrm{~S}$ concentrations in the southern portion of Lake Nakaumi (Station 18, 6 m water depth, has the largest seasonal change in oxic-anoxic conditions in Lake Nakaumi; Fig. 1) from May to October 2003 is summarized in Sakai et al. (2004). Bottom water temperatures range from approximately 16 to $23^{\circ} \mathrm{C}$, and the thermocline gradient at a depth of $3-4 \mathrm{~m}$ is relatively weak and ranges from 3 to $5^{\circ} \mathrm{C}$ The salinity of the epilimnion fluctuates widely, 6-20 psu, depending primarily on the amount of river water inflow (Tokuoka et al. 1994) and precipitation rates (Ohtake et al. 1982). In contrast, the salinity of the

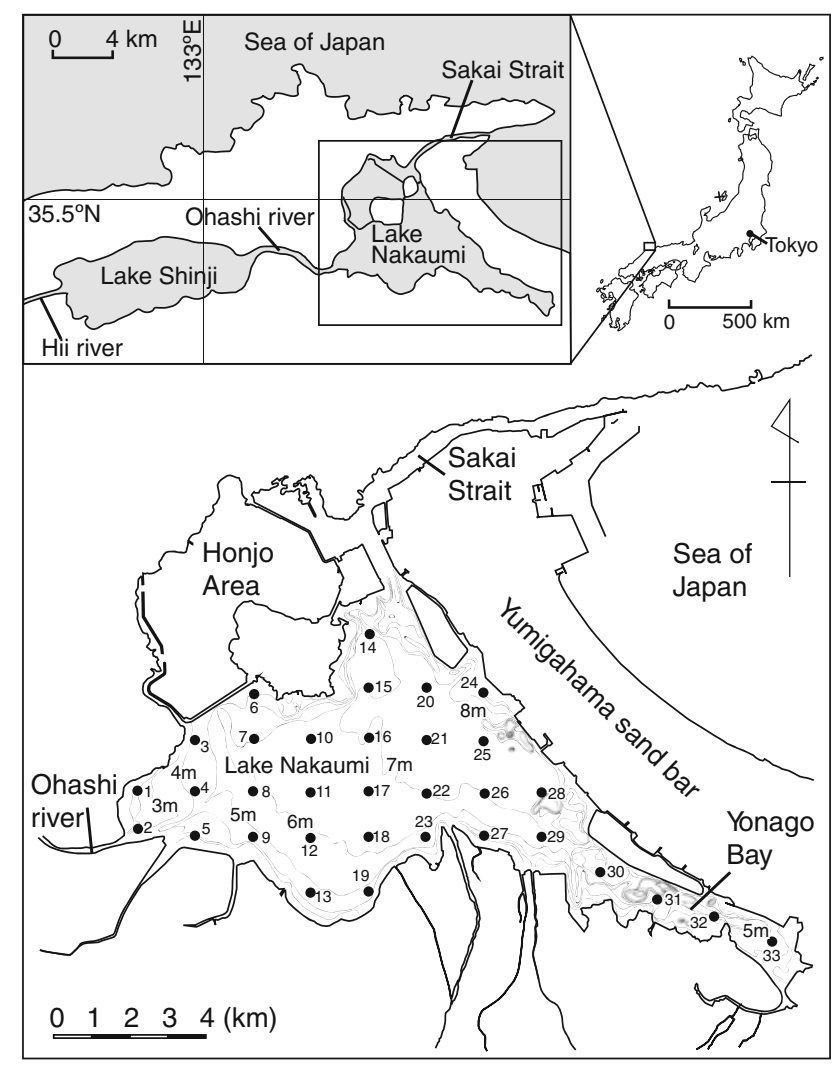

Fig. 1 Map showing sampling locations and bathymetry (in meters) in coastal brackish Lake Nakaumi. Sampling sites are numbered (1-33)

hypolimnetic water shows relatively little fluctuation, ranging from 27 to 32 psu. As a result, Lake Nakaumi was most strongly stratified by a halocline at a depth of 3-4 $\mathrm{m}$ in August and September 2003 when the precipitation rates were high, even though it is a shallow lake (Sakai et al. 2004). The upper water column is saturated with respect to DO due to gas exchange with the atmosphere and high phytoplankton activity. In contrast, DO decreases at the hypolimnion because the halocline prevents the vertical transport of oxygen and other dissolved components (Ohtake et al. 1980; Kondo et al. 1994; Seike et al. 1997). Anoxic water $\left(<0.5 \mathrm{mg} \mathrm{Ol}^{-1}\right)$ and $\mathrm{H}_{2} \mathrm{~S}$ were observed in hypolimnetic water from August to September 2003 at a depth below $5 \mathrm{~m}$ (Sakai et al. 2004).

Samples of the lake bottom water and the upper $\sim 1 \mathrm{~cm}$ of sediment were collected with a Niskin sampler and an Ekman-Birge type bottom sampler from 33 stations in Lake Nakaumi on 7-9 September 2003 (Fig. 1; Sakai et al. 2004). $\mathrm{H}_{2} \mathrm{~S}$ concentration was determined using a modification of the methylene blue method of Cline (1969) in order to avoid volatilization of $\mathrm{H}_{2} \mathrm{~S}$ and to simplify the sampling procedure (see Sakai et al. 2004). Sediment pore water was extracted by filling a $10 \mathrm{ml}$ capacity syringe with sediment from the upper $1 \mathrm{~cm}$ of a grab sample and squeezing it through a $0.45 \mu \mathrm{m}$ filter. Sediment remaining 
in the syringe was used for total organic carbon (TOC) analyses, which means that pore water $\mathrm{H}_{2} \mathrm{~S}$ and sediment TOC concentrations were analyzed from exactly the same material. TOC, total nitrogen (TN) and total sulfur (TS) concentrations were measured using a FISONS elemental analyzer EA1108 after removal of carbonates by addition of $1 \mathrm{M} \mathrm{HCl}$ (Sampei et al. 1997b). For pretreatment, $15 \mathrm{mg}$ of sample was placed in a $\mathrm{Ag}$ foil cup, and $1 \mathrm{M} \mathrm{HCl}$ added several times and dried at $110 \mathrm{C}$ for $60 \mathrm{~min}$. The dried sample was then wrapped in Sn foil for combustion. BBOT [(2,5-bis-5-tert-butyl-benzoxazol-2-yl)-thiophen: FISONS Instruments] was used as a standard, and standard regression line method was employed for quantitative analysis.

\section{Results and discussion}

$\mathrm{H}_{2} \mathrm{~S}$ distribution in the bottom and pore water

Based on the distribution of $\mathrm{H}_{2} \mathrm{~S}$ in bottom water, pore water and DO in bottom water (Fig. 2a-c; Sakai et al. 2004), three oxic-anoxic states (DO states) can be observed; DO State 1 (DOS1):in this clearly oxic waters, $\mathrm{H}_{2} \mathrm{~S}$ was not detected in either bottom or pore waters, DOS2: where $\mathrm{H}_{2} \mathrm{~S}$ was detected only in pore water and the overlying hypolimnion is anoxic to suboxic and DOS3: where $\mathrm{H}_{2} \mathrm{~S}$ was detected in both the bottom and pore waters, the hypolimnion was anoxic.
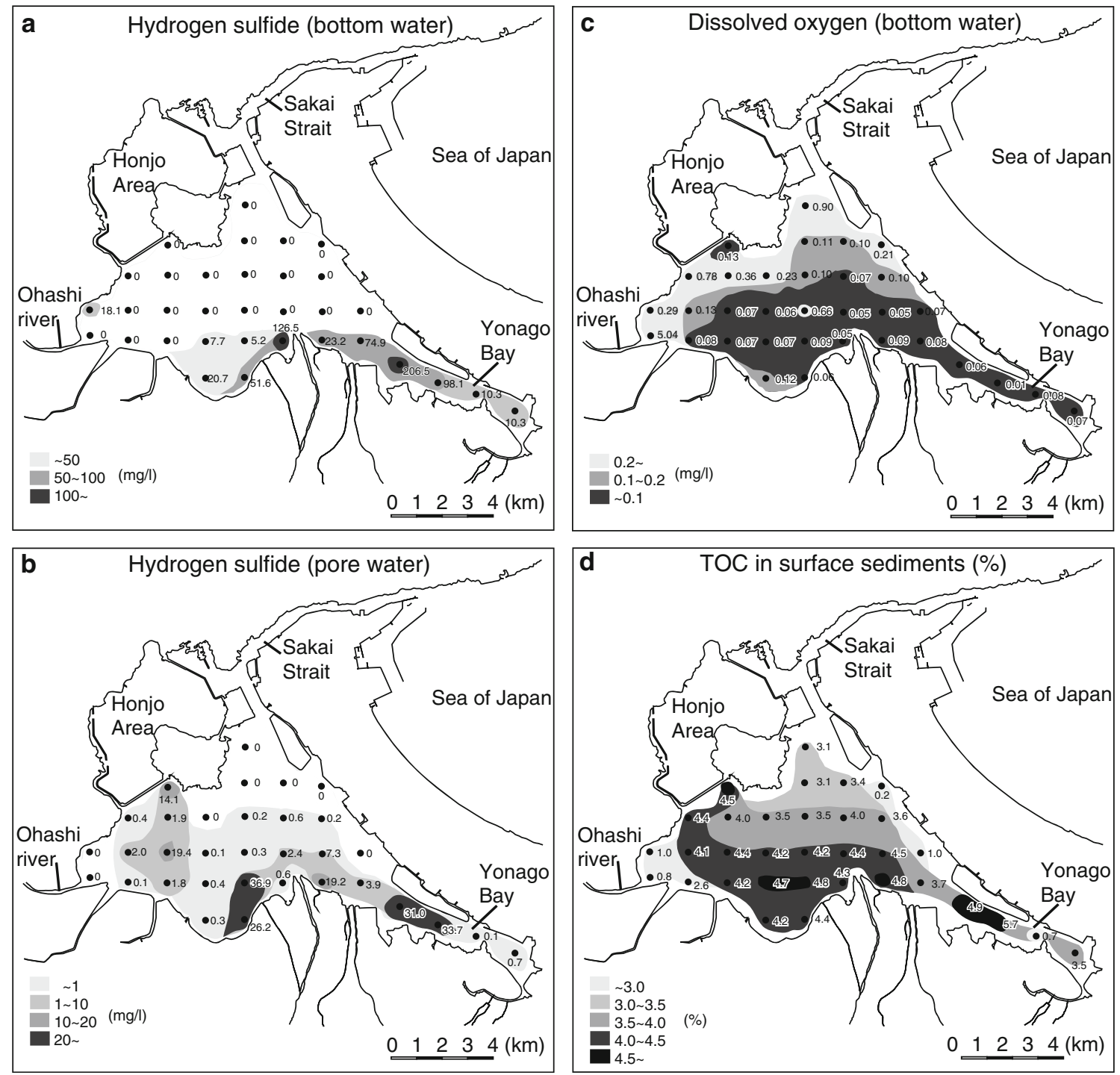

Fig. 2 Distribution of a hydrogen sulfide in bottom water, $\mathbf{b}$ hydrogen sulfide in surface sediment pore water, c dissolved oxygen (DO) concentration of bottom water $\mathbf{d}$ total organic carbon (TOC) contents

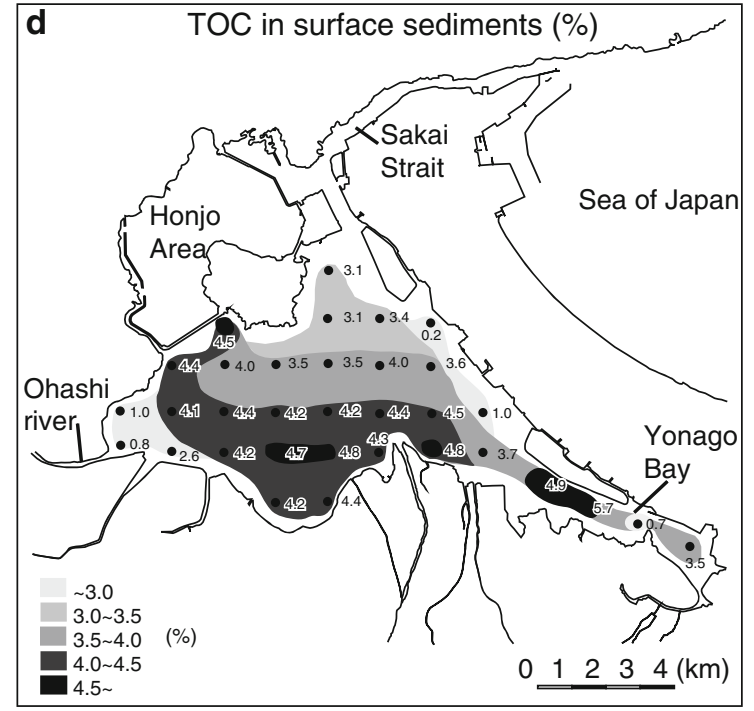

of surface sediment in brackish Lake Nakaumi, September 2003. $\mathbf{a}$ and $\mathbf{b}$ are modified from Sakai et al. (2004) 
Detailed characteristics of the three DO states:

1. DOS1: $\mathrm{H}_{2} \mathrm{~S}$ was not detected in pore waters near the Sakai-Strait (Station 10, 14, 15, 20, 24) and near the Ohashi River (Station 1-2). This is likely due to the inflow of oxygen-rich seawater $(>0.2 \mathrm{mg} / \mathrm{l}$ at Station $10,14,24 ;>0.1 \mathrm{mg} / \mathrm{l}$ at Station 15 and 20) and river water ( $>0.2 \mathrm{mg} / \mathrm{l}$ at Station 1 and 2) (Fig. 2c). Water depth at Stations 1 and 2, near the Ohashi River, is approximately $4 \mathrm{~m}$, equivalent to the depth of halocline. The sediments at these stations, therefore, are usually in contact with the oxic epilimnion.

2. DOS2: Pore water $\mathrm{H}_{2} \mathrm{~S}$ concentration in the western, central and eastern part of the lake were high $(0.4-$ $19.4 \mathrm{mg} \mathrm{S}^{-1}$; Station 3, 4-9, 11, 17, 21, 22, 25-26, 28 ), and correspond to DOS2 above, a sub-oxic to anoxic water column (DO are $>0.2 \mathrm{mg} / \mathrm{l}$ at Station 3, 7, 17; 1.0-2.0 mg/l at Station 4, 6, 25; <0.1 mg/l at Station $5,8,9,11,21,22,26,28)$ where $\mathrm{H}_{2} \mathrm{~S}$ is detected in pore water only (Fig. 2c). This result implies that DO in the hypolimnion is consumed by the decomposition of organic matter during transport of more saline water from the Sakai Strait to this region, which leads to bottom water anoxia.

3. DOS3: $\mathrm{H}_{2} \mathrm{~S}$ concentrations in the southern part of the lake and the Yonago-Bay area show relatively high values in both pore water $\left(0.1-44.2 \mathrm{mg} \mathrm{S}^{-1}\right.$; Station $12,13,18,19,23,27,29-33)$ and bottom water (5-207 $\mu \mathrm{g} \mathrm{S}^{-1}$ ) due to stagnant hypolimnetic water (DO is $<0.1 \mathrm{mg} / \mathrm{l}$ except for Station 13) (Fig. 2c) (Hashitani et al. 1990).

$\mathrm{H}_{2} \mathrm{~S}$ concentrations in pore waters were 10-200 times greater than those in the overlying water (Fig. 2a, b; Sakai et al. 2004). It can therefore be presumed that $\mathrm{H}_{2} \mathrm{~S}$ produced in the surface sediment diffuses into the overlying water. This suggests, that water circulation and diffusion replenishes some of the DO in bottom waters, due to the tidally driven physical mixing and influx of seawater, and that pore water has little opportunity to take up DO because of slow and limited circulation within the sediment (Ohtake et al. 1982; Seike et al. 1997). A study of Lake Nakaumi bottom water and surface sediments by Seike et al. (1997) showed that denitrification by acetylene reduction can proceed in reduced sediments even when oxic bottom water is present at the sediment-water interface. As a result, the $\mathrm{H}_{2} \mathrm{~S}$ of surface sediments in Lake Nakaumi may maintain anaerobic conditions long after the bottom waters return to oxic conditions as seen in DOS2. Thus, although anoxic conditions develop in the hypolimnion and at the sediment-water interface in summer seasons, the hypolymnion is affected by tidal-induced seawater and river water inflow, which contain high amounts of dissolved oxygen (Seike et al. 1997). In turn, various redox (oxic to anoxic) conditions are simultaneously present in Lake Nakaumi, allowing us to evaluate the quantitative relationship between $\mathrm{H}_{2} \mathrm{~S}$ concentrations and sedimentary organic matter (i.e., TOC contents) at the sediment-water interface.

Relationship between $\mathrm{H}_{2} \mathrm{~S}$ concentrations and TOC contents

The distribution of $\mathrm{H}_{2} \mathrm{~S}$ in pore water is very similar to that of the TOC content of surface sediment (Fig. 2b, d). High TOC contents $(>3.5 \%$; equivalent to the anoxic and unstable anoxic states-DOS2 and DOS3) were recorded in the western, central, and southern parts of the lake, and in the Yonago-Bay area (Fig. 2d). The sediments of the Sakai-Strait and Ohashi river areas contained relatively low TOC ( $<3.5 \%$; equivalent to DOS1). These results suggest that TOC content is related to redox conditions, and that the decomposition of organic matter is controlled by the inflow of oxic seawater and river water (Kurakado et al. 1998). Figure 3 shows that the $\mathrm{H}_{2} \mathrm{~S}$ concentration of pore water is characteristically related to TOC content of the surface sediment. In areas where TOC content is less than $3.5 \%, \mathrm{H}_{2} \mathrm{~S}$ concentration in both bottom and pore water is zero or extremely low, whereas in areas above $3.5 \%$ TOC, $\mathrm{H}_{2} \mathrm{~S}$ was detected and correlated with TOC content. A linear relationship between sediment TOC and hydrogen sulfide concentration in pore water is present when TOC content is above $3.5 \%$ : pore water $\mathrm{H}_{2} \mathrm{~S}(\mathrm{ppm})=13.9 \times$ TOC $(\%)-52.1$ [correlation coefficient is $0.72(n=18)$ ]. The slope of this relationship suggests that the $\mathrm{H}_{2} \mathrm{~S}$ content in pore water increases by $\sim 14 \mathrm{ppm}$ for every $1 \%$ increase in sediment TOC above $3.5 \%$.

In general, the rate of bacterial sulfate reduction is controlled by the availability of both dissolved sulfate and organic matter (Berner 1984). When dissolved sulfate

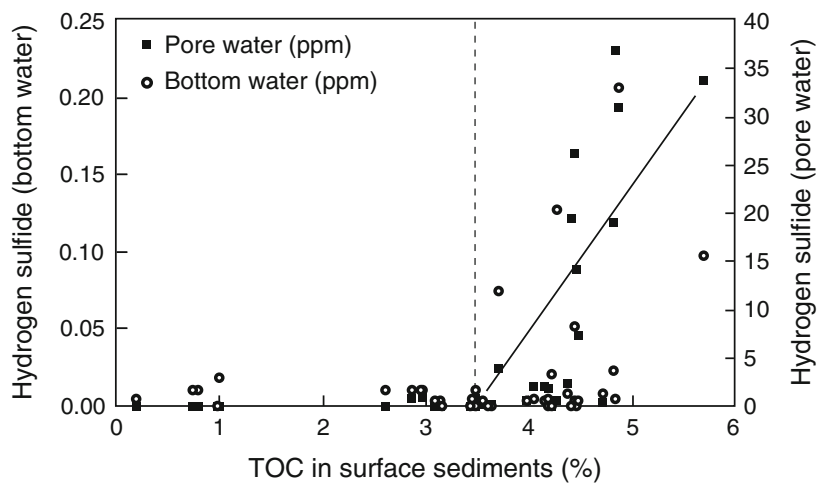

Fig. 3 Hydrogen sulfide concentration in bottom and pore water compared to TOC content. Note that hydrogen sulfide was above detection limits only in sediments with TOC $>3.5 \%$. Above $3.5 \%$ TOC the coefficient of correlation is 0.72 . Pore water $\mathrm{H}_{2} \mathrm{~S}$ $(\mathrm{ppm})=13.9 \times$ TOC $(\%)-52.1$, TOC $>3.5 \%$ 
content is above $\sim 5 \mathrm{mM}$ (less than $15 \%$ of the seawater sulfate value) sulfate is not rate limiting for bacterial sulfate reduction, as was shown using a ${ }^{35} \mathrm{~S}$ tracer (Boudreau and Westrich 1985). In case of Lake Nakaumi, the salinity of the bottom environment is about 27-32 psu (i.e., near marine sulfate content), which indicates that ample sulfate is available for sulfate reduction (Kaplan et al. 1963). As a result, the major factor controlling $\mathrm{H}_{2} \mathrm{~S}$ production derived from bacterial sulfate reduction at the SWI in Lake Nakaumi is the amount and reactivity of organic matter deposited in the sediment (Berner 1984). Several studies have suggested that the rate and efficiency of sulfate reduction depends on the type of organic matter present, primarily the degree of preservation of freshly deposited planktic organic matter (Westrich and Berner 1984; Sampei et al. 1997c). The $\mathrm{C} / \mathrm{N}$ ratios of the surface sediment organics in Lake Nakaumi analyzed in this study are 7-9 at most sampling stations in the lake. Figure 4 shows that TOC has a good correlation with $\mathrm{TN}$ with positive slope of about 8.7, which indicates that this organic matter is derived mainly from planktic organisms (Bordowskiy 1965; Sampei and Matsumoto 2001). Lake Nakaumi is likely to be rich in planktic organics: the water depth is shallow; the lake is easily stratified and bottom water is seasonally anoxic; and both primary productivity and sedimentation rates are high (1-2 mm year ${ }^{-1}$; Nakano-umi and Shinji-ko Research Group et al. 1987; Shinji-ko Research Group et al. 1986; Sampei et al. 1997a). In most settings, organic burial rate and the degree of preservation of organic matter are positively correlated with total sedimentation rate (Berner 1989). Therefore, the planktic organic matter in Lake Nakaumi may be less oxidized and have spent less time in the water column or at the sediment surface (as freshly-deposited organic matter) in comparison with the marine depositional environment (Sampei et al. 1997c). The surface sediments of Lake Nakaumi, therefore, have a high rate of bacterial sulfate reduction because of the high reactivity of organic matter. Consequently, the limiting factor for bacterial sulfate reduction at the SWI in Lake Nakaumi is the amount of TOC. The $\mathrm{H}_{2} \mathrm{~S}-\mathrm{TOC}$ relationship of this study shows that the TOC content threshold for the production of $\mathrm{H}_{2} \mathrm{~S}$ in surface sediment is $3.5 \%$. In addition, sediment TS content, dominated by iron sufide-S (Sampei et al. 1992), is also related to $\mathrm{H}_{2} \mathrm{~S}$ content (Fig. 5). $\mathrm{H}_{2} \mathrm{~S}$ is only detected in regions above $1.2 \%$ sediment TS content. This suggests that the basic driving force behind iron sulfide-S formation (TS) is the amount of reactive organic matter in combination with $\mathrm{H}_{2} \mathrm{~S}$ in the pore water (Berner 1989). This has also been documented by Lin and Morse (1991), who showed a relationship between organic carbon and sulfate reduction/ion sulfide mineral formation in anoxic sediments of the Gulf of Mexico.

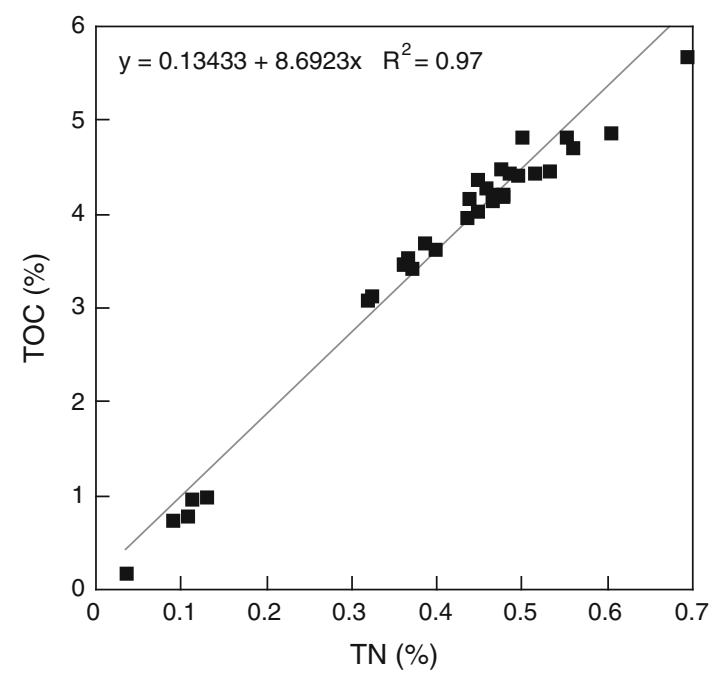

Fig. 4 Total organic carbon (TOC) vs. total nitrogen (TN). TOC has a good correlation with $\mathrm{TN}$ with positive slope of about 8.7

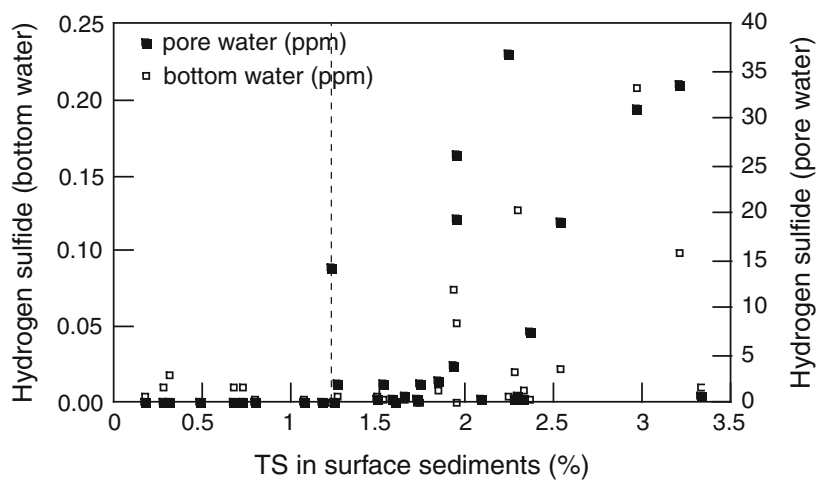

Fig. 5 Hydrogen sulfide concentrations of the bottom and pore water compared to total sulfur (TS) contents. Note that hydrogen sulfide was only detected in sediments with TS $>1.2 \%$

Use of the $\mathrm{H}_{2} \mathrm{~S}$-TOC relationship in multi-decadal environmental history studies

Using this $\mathrm{H}_{2} \mathrm{~S}-\mathrm{TOC}$ relationship, it is possible to estimate the distribution of $\mathrm{H}_{2} \mathrm{~S}$ generating regions in Lake Nakaumi from the threshold TOC content $(3.5 \%)$. Sediment TOC contents in Lake Nakaumi have been mapped a number of times since the 1960s (Mizono et al. 1969; Ono and Onodera 1976; Kurakado et al. 1998) (Fig. 6). Beginning in the 1960s there has also been significant modification of the lake through the Nakaumi reclamation and freshening project, conducted by the Ministry of Agriculture and Forestry (Date 1978). The purpose of this project was to reclaim a total of $28 \mathrm{~km}^{2}$ of agricultural lands from Lake Nakaumi, and also to convert the remaining lake area of some $3 \times 10^{8} \mathrm{~m}^{3}$ into a fresh water reservoir to supply irrigation water for the newly reclaimed lands. The physical hydrography of Lake Nakaumi has been greatly 

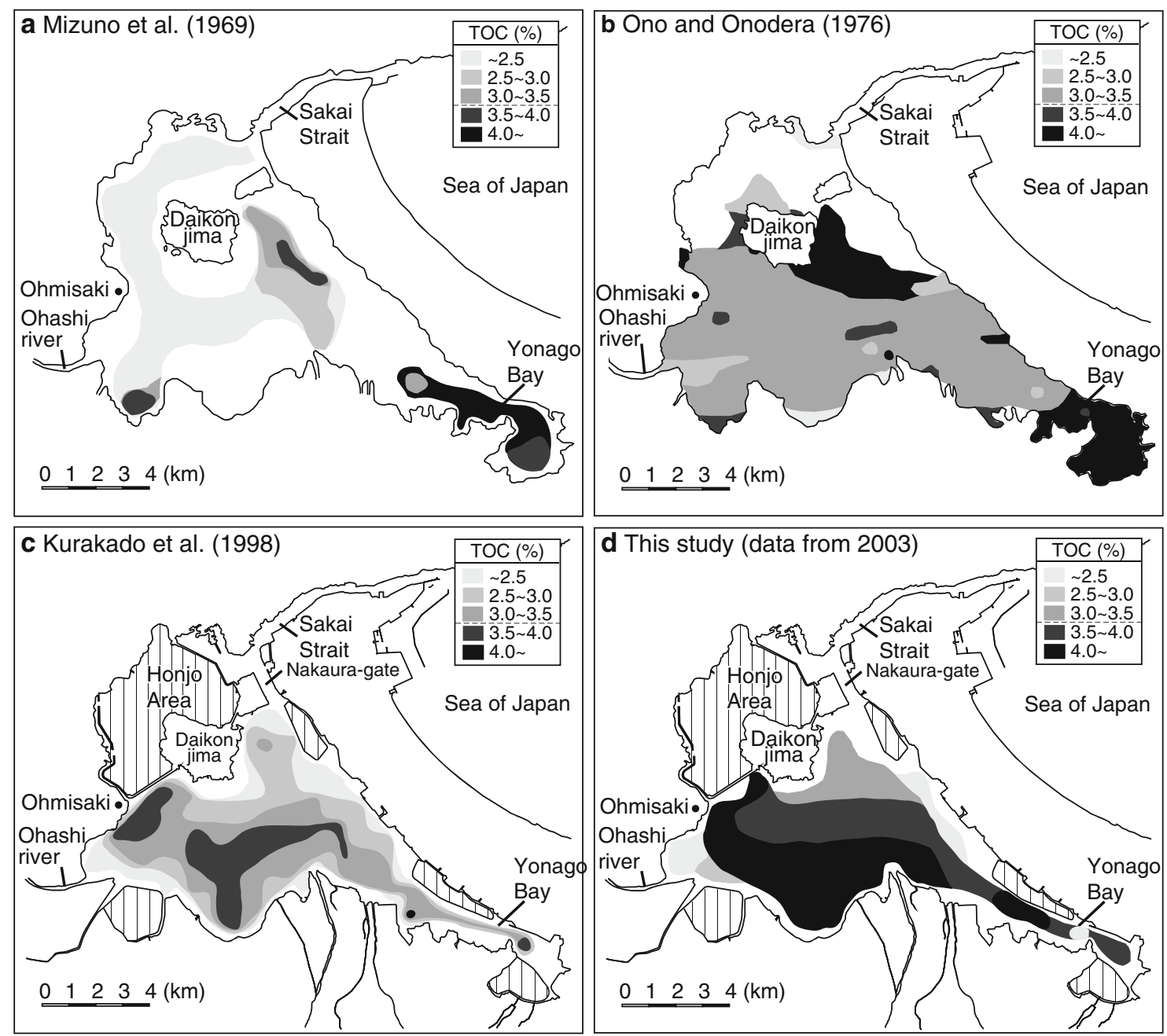

Fig. 6 Historical TOC distribution of surface sediments in Lake Nakaumi. a Mizono et al. (1969) b Ono and Onodera (1976) c Kurakado et al. (1998) $\mathbf{d}$ this study. Hatched areas denote areas isolated by polder dams. a and b prior to polder dam construction

changed by reclamation activities, including enlargement and deepening of channels, the construction of the Nakaura water-gate during 1968-1974 (Fig. 6c, d), and construction and later modification of the polder dykes which are surrounding Honjo Area during 1978-1981 (Fig 6c, d). Prior to the reclamation activities, seawater entering from the Sakai Strait primarily flowed north of Daikon-jima toward the center of the lake, leading to a generally counterclockwise circulation pattern (Fig. 6a, b). After the dyking of the Honjo area, completed in 1982, this westward flow was completely blocked and the seawater from Sakai strait flowed southward through the Nakaura-gate toward the center of the lake (Fig. 6c, d). At present water exchange with the open ocean is allowed only through the Nakauragate.

TOC distributions have very different patterns before (Fig. 6a, b) and after (Fig. 6c, d) the Nakaumi reclamation project construction was completed. Areas with TOC contents greater than $3.5 \%$ are generally on the eastern half of the lake, south of Daikon-jima, and in Yonago-Bay before the construction (Fig. 6a, b). After construction TOC is highest in the western, central, and southern parts of the lake, and in Yonago-Bay (Fig. 6c, d). These results suggest that the change in circulation within the lake associated with the reclamation project construction activity significantly affected the distribution of TOC in the lake's surface sediments. The impact of Nakaumi reclamation project was a drastic change in the redox conditions at the SWI, the place of the organic matter decomposition/ oxidation, because the delivery of oxic waters is the only source of oxidants (mainly $\mathrm{O}_{2}$ ) and the flow and flux of both seawater and river water to the lake was modified by the reclamation works. The area characterized by TOC greater than $3.5 \%$ has progressively increased in the last four decades, which implies an increase in the $\mathrm{H}_{2} \mathrm{~S}$ producing environments (Fig. 6a-d).

In the summer of 2000 the Nakaumi reclamation project was abandoned, and at the end of 2002 the desalination 
project was also canceled when it became clear that alternative water supplies existed for agriculture in this region. As a result, Lake Nakaumi survived as a coastal lagoon, but large artificial structures wall off one-third of the lake area and have modified the topography, circulation, and bottom environments of the lake as clearly shown in this study.

In conclusion, the TOC- $\mathrm{H}_{2} \mathrm{~S}$ relationship of the sediment-water interface shown in this study may be a useful indicator for mapping the distribution of $\mathrm{H}_{2} \mathrm{~S}$ production in brackish systems similar to Lake Nakaumi (having a high $\mathrm{SO}_{4}{ }^{2-}$ supply available to the bottom waters and surface sediments rich in planktic organic matter). These observations may be a guide for the historical evaluation of its negative effects on aquatic ecosystems.

Acknowledgments We thank A. Taira and H. Kitazato for giving us an opportunity to study the brackish lake system; M. Matsumoto for his valuable advice during surveys; Y. Seike and staff of Research Center for Coastal and Lagoon Environments of Shimane University for their instruction and support during experiments.

Open Access This article is distributed under the terms of the Creative Commons Attribution License which permits any use, distribution, and reproduction in any medium, provided the original author(s) and the source are credited.

\section{References}

Berner RA (1984) Sedimentary pyrite formation: an update. Geochim Cosmoshim Acta 48:605-615

Berner RA (1989) Biogeochemical cycles of carbon and sulfur and their effect on atmospheric oxygen over Phanerozoic time. Palaeogeogr Palaeoclimatol Palaeoecol (Global and Planetary Change Section) 75:97-122

Bordowskiy OK (1965) Accumulation of organic matter in bottom sediments. Mar Geol 3:33-82

Boudreau BP, Westrich JT (1985) The dependence of bacterial sulfate reduction on sulfate concentration in marine sediments. Geochim Cosmochim Acta 48:2503-2516

Cline JD (1969) Spectrophotometric determination of hydrogen sulfide in natural waters. Limnol Oceanogr 3:454-458

Date Y (1978) The Nakanoumi reclamation and freshening project basic operation programs and the natural water environment of Lake Nakanoumi. Suirikagaku 104:43-69 (in Japanese)

Date Y, Hashitani H, Seike Y, Kondo K, Okumura M, Fujinaga K (1989) Water quality of Lake Nakaumi and Lake Shinji as seen from the results of monthly observation for 12 years-seasonal variation, secular variation typical value. Studies of San'in Region (Natural Environment), vol 5. Center for Studies of the San'in Region, Shimane University, pp 89-102 (in Japanese with English abstract)

Hashitani H, Okumura M, Kondo K, Seike Y (1990) Bottom water environments in Lake Shinji and Lake Nakaumi. Studies of the San'in Region (Natural Environment). Shimane Univ. 6:137-150 (in Japanese with English Abstract)

Kaplan IR, Emery KO, Rittenberg SC (1963) The distribution and isotopic abundance of sulfur in recent marine sediments off southern California. Geochim Cosmochim Acta 27:297-331
Kondo K, Seike Y, Hashitani H (1994) The role of halocline on the control of vertical distribution of nutrients and phytoplankton in brackish Lake Nakaumi. Limnol 55:47-60

Kurakado Y, Sampei Y, Takayasu K, Tokuoka T, Inouchi Y (1998) Distribution of organic carbon, nitrogen and sulfur contents in surface sediments of brackish coastal lakes Nakaumi and Hamana. Japan. LAGUNA 5:123-135 (in Japanese with English abstract)

Lin S, Morse JW (1991) Sulfate reduction and iron sulfide mineral formation in Gulf of Mexico anoxic sediments. Am J Sci 291:55-89

Mizono A, Sekine S, Nakazawa J, Takaku A, Onodera K, Ono M (1969) Uranium concentration in the bottoms of the Lake Shinjiko and Lake Naka-umi, with the special reference to its genetic relationship with sedimentary environment. Bull Geol Sur Jpn 19:317-352 (in Japanese with English Abstract)

Nakano-umi and Shinji-ko Research Group, Matsumoto E, Inouchi Y, Kashima K (1987) Natural history of the Nakano-umi and Shinji Lakes-VI. Core sampling in 1986 and preliminary report on foraminiferal and diatom assemblages in the bottom sediments of the Lake Nakano-umi. Geol Rep Shimane Univ 6:61-84 (in Japanese)

Nakano-umi and Shinji-ko Research Group, Matsumoto E, Inouchi Y, Mizuno A (1986) Natural history of the Nakano-umi and Shinji Lakes-V. Core sampling of the Lake Shinji in 1985. Geol Rep Shimane Univ 5:11-18 (in Japanese)

Nedwell DB, Abram JW (1979) Relative influence of temperature and electron donor and electron acceptor concentrations on bacterial sulfate reduction in salt marsh sediment. Microb Ecol 5:67-72

Ohtake H, Date Y, Kondo K, Seike Y, Nakane S (1980) Studies on the brackish water environment of Lake Nakaumi with special reference to the reclamation and freshening project. Verh Int Verein Limnol 21:581-586

Ohtake H, Kondo K, Seike Y, Date Y (1982) Seasonal and areal features of the lagoonal environment in Lake Nakaumi, a shallow coastal lagoon in Japan. Hydrobiologia 97:15-26

Ono M, Onodera K (1976) Organic carbon in the bottom sediments from Lake Shinjiko and Lake Nakaumi on the coast of Japan Sea, west Japan. Bull Geol Sur Jpn 27:535-553

Ramm AE, Bella PA (1974) Sulfide production in anaerobic microcosms. Limnol Oceanogr 19:425-441

Sakai S, Nakaya M, Takayasu K (2004) Hydrogen sulfide distribution in bottom and pore waters during an anoxic period in Lake Nakaumi, Japan. Laguna 11:65-68

Sampei Y, Matsumoto E (2001) C/N ratios in a sediment core from Nakaumi lagoon, southwest Japan usefulness as an organic source indicator. Geochem J 35:189-205

Sampei Y, Takasu A, Szuzuki N, Tokuoka T (1992) Vertical distribution of $\mathrm{C}, \mathrm{S}$ and $\mathrm{Fe}$ within the core sediments from Lake Nakaumi: elementary color mapping of lake sediments by electron probe microanalyzer. Studies of the San'in Region, Shimane University 8:11-20 (in Japanese with English abstract)

Sampei Y, Matsumoto E, Tokuoka T, Inoue D (1997a) Changes in accumulation rate of organic carbon during the last 8000 years in sediments of Nakaumi Lagoon, Japan. Mar Chem 58:39-50

Sampei Y, Matsumoto E, Kamei T, Tokuoka T (1997b) Sulfur and organic carbon relationship in sediments from coastal brackish lakes in the Shimane peninsula district, southwest Japan. Geochem J 31:245-262

Sampei Y, Kurakado Y, Shimizu A, Takayasu K, Ishida H (1997c) Distribution of organic carbon, nitrogen and sulfur in surface sediments of Lake Saroma and Lake Abashiri, Hokkaido, Japan. Res Org Geochem 12:51-60

Seike Y, Okumura M, Fujinaga K (1997) Nitrification and denitrification in anoxic water in the brackish Lake Nakaumi. Bull. Coastal Oceanogr (Engan Kaiyo Kenkyuu) 35:27-33 (in Japanese with English abstract) 
Tokuoka T, Onishi I, Takayasu K, Mitsunashi T (1990) Natural history and environment changes of Lakes Nakaumi and Shinji. Origin, Environment and Geology (Inouchi, Y. et al., eds.). Mem Geol Soc Jpn 36:15-34 (in Japanese with English Abstract)

Tokuoka T, Onishi I, Sampei Y, Takayasu K, Anma K, Tsuchiya Y, Matsuda S, Inouchi Y, Nishimura K (1994) A wedge-like saline layer in Lakes Nakaumi and Shinji detected by sonic survey, and its significance. Laguna 1:11-26 (in Japanese with English abstract)

Westrich JT, Berner RA (1984) The role of sedimentary organic matter in bacterial sulfate reduction: the G model tested. Limnol Oceanogr 29:236-249 